\title{
Tuber Yield and Yield Component Performance of Cassava (Manihot esculenta) Varieties in Fafen District, Ethiopia
}

\author{
Chanie Derso Misganaw ${ }^{1}{ }^{1}$ and Walelign Demisie Bayou ${ }^{2}$ \\ ${ }^{1}$ Department of Biotechnology, Wollo University, Dessie, Ethiopia \\ ${ }^{2}$ Department of Dryland Crop Science, Jigjiga University, Jigjiga, Ethiopia \\ Correspondence should be addressed to Chanie Derso Misganaw; chaniederso@gmail.com
}

Received 8 November 2019; Accepted 12 March 2020; Published 13 April 2020

Academic Editor: Maria Serrano

Copyright (c) 2020 Chanie Derso Misganaw and Walelign Demisie Bayou. This is an open access article distributed under the Creative Commons Attribution License, which permits unrestricted use, distribution, and reproduction in any medium, provided the original work is properly cited.

\begin{abstract}
Since there is a variety of performance in cassava varieties for different agroecologies and there was no cassava production before in Ethiopian Somali regional state, Fafen district in particular. Investigation of the performance of higher tuber yielded cassava variety is the main concern for this study. Thus, the objective of this study was to evaluate tuber yield performance of cassava varieties. To do so, four varieties (kello, Qulle, Hawassa-4, and Chichu) were collected from Hawassa Agricultural Research Center and planted in Fafen district where there is arid climatic condition. Thirty-centimeter-long stakes were planted with $1 \mathrm{~m} \times 1 \mathrm{~m}$ intra- and inter-row spacing with Randomized Complete Block Design (RCBD). There were four rows, five plants per row and twenty plants per plot. Phenological, growth, and agronomic parameters were analyzed using SAS software; mean differences were compared using LSD at $p \leq 0.05$. The result revealed that days to $50 \%$ establishment of the stem cuttings of variety "Qulle" were performed within 15.6 days. Among all varieties, Chichu and Hawassa- 4 had the highest number of plant stand count, 88.3 and $86.7 \%$, respectively. The highest number of mean multiplication ratio, secondary branches per plant, and mean plant height were obtained with variety "Qulle." With regards to tuber yield and its components, there was significant difference among understudied cassava varieties. The highest tuber yield ( $23.93 \mathrm{t} / \mathrm{ha})$ was registered in variety "Hawassa- 4 " followed by Kello (19.90 t/ha) and Qulle (18.73 t/ha). It implies that variety "Hawassa-4" performed best in the test area and hence recommended in test area.
\end{abstract}

\section{Introduction}

Cassava (Manihot esculenta Crantz) is a shrub species which belongs to the Euphorbiaceae family that grows continuously, with alternating plant growth periods and carbohydrate storage in its tuberous roots followed by periods of dormancy [1]. It is very important for the agroeconomy of several tropical countries because of its broad adaptation to a variety of soil, climate, drought tolerance, and ability to grow on marginal soil [2].

Africa produces over $54 \%$ of the world's cassava, with Nigeria leading the global with a production of about 54.8 million ton in 2014 [3]. Due to being easier for growth, famine secure, the ability to be left in the ground for a long time before harvesting, it has been growing by small-scale and subsistence farmers in South Africa [4]. About 70\% of the total cassava production, for roots and leaves, is utilized as human food in Mozambique and East Africa countries (Tanzania, Kenya, Uganda, Rwanda, and Burundi) accounts about $11 \%$ of the total production of cassava in Africa [4]. Its starchy roots and edible leaves provide food for $800 \mathrm{M}$ people globally, many of whom manage to survive on it due to its drought tolerance and requiring little in the way of inputs [5], and it generates billions of income both for families and government and then contributes a lot to food security at several levels [6]. In Ethiopia, cassava, locally known as Mita Boye, Yenchet Boye Furno tree, and Mogo, has been used in cultivation, particularly, in the south, south west, and western parts since its introduction in the $19^{\text {th }}$ century [7]. 
Cassava grows between 480 and 1800 meters above sea level within the temperature range of 15 to $30^{\circ} \mathrm{C}$ and 692 to $1470 \mathrm{~mm}$ annual rainfall [8]. It cultivates best on moist, deep, and relatively low fertile light sandy loams or loamy sands [9]. In traditional systems, cassava can be intercropped with other crops such as maize, sorghums, cowpeas, and sweet potatoes, but sole cropping is more common [10].

Its starchy tuberous roots yield $25-35 \%$ starch which provide food for over 500 million people for small-scale and subsistence farming in developing countries [11]. By different forms of products such as chips, pellets, flour, and starch, it contributes to the economy of exporting countries in international trade [12]. A high quality cassava is also alternative to wheat in rural and urban households [13] and, therefore, is used to replace wheat flour in food and nonfood industries [14]. In southern Ethiopia, roots are consumed after washing and boiling in the form of bread and injera by mixing with cereals (teff, maize, and sorghum) and used for local behaverage (areki and tela) [15]. In general, it is used for citric acid production, paper making, food processing, lower blood pressure, lubricants, adhesives, and textiles and recently for bioethanol production too [16].

Cassava is propagated vegetatively by stem cuttings which make it very advantageous [17]. Stem cuttings, horticultural "stakes", were on average at least $20 \mathrm{~cm}$ long with 4 to 5 nodes of viable buds and were transported carefully to avoid damage [18]. The cuttings can be plant either vertically, inclined, or horizontally at different planting depths on ridges, mounds, or flat ground [19]. Despite very low planting material multiplication rate $(1: 10)$ compared to cereals $(1: 200)$ [20], storage, and bulkiness in handling, propagation via stem cutting is still the most feasible alternative for small-scale farmers as compared to the use of seed [21].

Cassava is a major source of carbohydrate. However, its production is limited, only in a few areas in Ethiopia. Moreover, yielding performance of the local varieties is low and showed different performance in various agroecologies. Besides, only limited researches have been conducted in Ethiopia [8]. Therefore, it is essential to enhance efforts to initiate and investigate the performance of cassava to Fafen district where there is arid climatic conditions in contribution for poverty reduction, not only to target area, but also it will be important in a similar trend. Besides, the production of the crop in such areas is the best alternative to overcome food scarcity when other crops are predisposed for drought. Thus, the objective of this study was to evaluate the performance of cassava varieties for tuber yield in Fafen district, Ethiopian Somali Regional State.

\section{Materials and Methods}

2.1. Description of the Study Area. This study was conducted under field conditions in Fafen district of Ethiopian Somali Regional state using supplementary irrigation in the cropping season of $2017 / 18$. The type of soil with the study area is sandy loam. The mean annual temperature ranges from 15.0 to $29.3^{\circ} \mathrm{C}$. The minimum and maximum mean annual rainfall is $300 \mathrm{~mm}$ and $500 \mathrm{~mm}$, respectively. There are two rainy periods. March and April are short rainfall periods while July and August are the main rainy periods in the study area. The topography comprises extensive plains and also some hills. There are above 180 smallholder farmers around the study site and $75 \%$ of them needed to cultivate their farm land and liked to scale up industry level.

2.2. Stem Cutting Preparation. Mature and health stem cuttings were obtained from Hawassa Agricultural Research Center, center of excellence in cassava production in the country, Ethiopia. The stem cuttings of each cassava variety were collected from the middle stems of the respective seven-month-old mother plant. In order to reduce evaporation and drying, they were covered with grass while transporting to the plantation area which is about $650 \mathrm{~km}$ far from collection site. Each stem cutting was cut with $30 \mathrm{~cm}$ in length and 4-5 nodes soon before planting.

2.3. Treatments and Experimental Design. In this study, Randomized Complete Block Design (RCBD) was employed. The experiment was carried out under field conditions using four varieties as treatments, namely, Kello, Qulle, Hawassa-4, and Chichu, with three replications. The experimental field was ploughed and harrowed properly before planting. The plots were $5 \mathrm{~m}$ long and $4 \mathrm{~m}$ wide, with intrarow spacing of $1 \mathrm{~m}$ and $1 \mathrm{~m}$ interrow. Therefore, the total size of each plot was $20 \mathrm{~m}^{2}$. The cuttings were planted with inclined $\left(45^{\circ}\right)$ stake orientation on $28^{\text {th }}$ of May, 2017. Totally, there were 20 plants per plot for each variety, five plants in each row. Throughout experimental period, earthing up, weeding, and supplementary irrigation activities were carried out uniformly whenever required.

2.4. Data Collection. Quantitative data on phenological parameters (days to 50\% establishment within 15-30 days and final establishment in the period of three months), growth parameters (plant height, number of primary stems per stake, number of secondary branches per plant, and multiplication ratio per stake) at the end of the ninth month and on the tenth month, and the agronomic parameters (number of tubers per plant, average length of tubers per plant, average diameter of tubers per plant, tuber yield per plot, total tuber yield per hectare, tuber fresh weight, tuber dry weight, and the tuber dry matter content) were recorded carefully. For those parameters, the plants on the boundaries were discarded, and, therefore, six representative plants were taken from the middle rows of each plot from the respective treatments. Besides, the qualitative data were composed and summarized accordingly. Tuber yield per hectare was calculated as follows:

$$
\text { Yield per hectare }\left(\frac{\mathrm{t}}{h a}\right)=\frac{\text { yield per plot }(\mathrm{kg}) \times 10,000 \mathrm{~m}^{2}}{6 \mathrm{~m}^{2}(\text { net plot size }) \times 1000(\mathrm{~kg} / \mathrm{t})},
$$

where 1 hectare $(\mathrm{ha})=10,000 \mathrm{~m}^{2}$ and 1 tone $(\mathrm{t})=1000 \mathrm{~kg}$. For tuber dry matter content, tubers from each plant were peeled and cut into small pieces and weighed to get fresh 
weight. Then, it was put into oven dried with $105^{\circ} \mathrm{C}$ for 24 hours. After that, it was weighed again to determine the dry weight.

$$
\mathrm{DM} \%=\frac{\text { tuber dry weight }(\mathrm{g})}{\text { tuber fresh weight }(\mathrm{g})} \times 100 .
$$

2.5. Data Analysis. The data were analyzed statistically by analysis of variance (ANOVA) according to [22] using SAS 9.1.3 software at $p \leq 0.05$ (SAS Institute Inc., 2008). Differences between means were compared using the least significance difference (LSD) test at $p \leq 0.05$ and their correlation. Other qualitative data were also presented.

\section{Results}

3.1. Survival Rate of Cassava Varieties. In this study, $50 \%$ of the stakes were survived within two weeks (15.33 days) for variety "Qulle," whereas "Kello" took 26.30 days. There was no statistical significant difference $(p \geq 0.05)$ between "Qulle" and "Chichu" varieties. With regards to final plant stand, $88.32 \%$ of "Chichu" was fully established. But no statistical significant difference $(p \geq 0.05)$ was seen with "Hawassa-4." The lower percentage of plant stands $(80.00 \%$ and $81.61 \%$ ) were observed with "Kello" and "Qulle," respectively (Table 1).

3.2. Growth Performance of Cassava Varieties. The vegetative growth of all varieties was slower in the first three months and showed fast growth at the fourth and fifth months with wide canopy. With regards to stem thickness, the cassava varieties were ordered as Kello, Qulle, Chichu, and Hawassa4 in decreasing manner.

The results revealed that most above-ground growth components showed different performance across varieties (Table 2). The highest mean number of primary stems (2.39) was produced from "Chichu," whereas "Kello" showed the lowest number of primary stems per stake (1.61). However, statistically, there was no significant differences $(p \geq 0.05)$ between "Chichu" a variety with the highest number of primary stems per stake and the remaining two varieties, "Hawassa-4" and "Qulle." All the varieties showed significant differences $(p \leq 0.05)$ in secondary branches per plant (Table 2). The highest number of secondary branches (7.61) was obtained in "Qulle" whereas the lowest (2.56) was recorded in "Chichu." Similarly, "Qulle" showed the highest plant height $(148.56 \mathrm{~cm})$ followed by "Chichu” $(121.89 \mathrm{~cm})$. The lowest plant height $(98.61 \mathrm{~cm})$ was recorded in "Hawassa-4." The highest amounts of planting materials per stake were produced from "Qulle" (24.94), while the lowest planting materials (8.94) were obtained from "Kello." In all studied growth parameters "Qulle" showed the highest value compared to the rest of the varieties.

\subsection{Tuber Yield and Yield Components of Cassava Varieties.} There were significant differences $(p \leq 0.05)$ among tested varieties in tuber yield and its component (Table 3 ). The
TABLE 1: Days to $50 \%$ establishment and final establishment of four cassava varieties.

\begin{tabular}{lcc}
\hline Varieties & Days to $50 \%$ establishment & Final establishment (\%) \\
\hline Kello & $26.30^{\mathrm{c}}$ & $80.00^{\mathrm{b}}$ \\
Hawassa-4 & $22.51^{\mathrm{bc}}$ & $86.70^{\mathrm{a}}$ \\
Qulle & $15.33^{\mathrm{a}}$ & $81.61^{\mathrm{b}}$ \\
Chichu & $18.67^{\mathrm{ab}}$ & $88.32^{\mathrm{a}}$ \\
Mean & 20.70 & 84.16 \\
CV (\%) & 22.90 & 4.70 \\
\hline
\end{tabular}

highest number of tubers per plant (6.50) was recorded in variety "Hawassa-4" and the lowest (4.06) was recorded in variety "Chichu." Although the longest tuber per plant $(25.39 \mathrm{~cm})$ was registered in "Kello," statistically, it has no significant difference $(p \geq 0.05)$ with "Qulle." The largest tuber in diameter $(3.87 \mathrm{~cm})$ was obtained in variety "Hawassa-4" and the smallest was recorded in "Chichu." The highest tuber yield was recorded in variety "Hawassa-4" (23.93 t/ha) followed by "Kello" (19.90 t/ha) and "Qulle" (18.73 t/ha). Similarly, the dry matter content of "Hawassa4" $(50.3 \%)$ and "Kello" (44.62\%) was the highest and had no significant difference $(p \geq 0.05)$ between each other. It indicates that variety "Hawassa-4" could be preferred in test area followed by "Kello."

3.4. Relationship of Yield and Yield Components. The correlation matrix showed that tuber yield showed highly significant positive correlation to some yield components (tuber number, tuber length, and tuber diameter per plant). On the other hand, it was negatively correlated to primary stems, plant height, and multiplication ratio (Table 4).

\section{Discussion}

4.1. Survival Rate of Cassava Varieties. A day to 50\% establishment is an indicator that ensures crops survival. Accordingly, variety "Qulle" with fewer days to 50\% establishment implies the variety survived earlier, whereas "Kello" took longer days than the remaining varieties. This results in "kello" to have the lowest final stand count. Similarly, the earliest establishment of "Chichu" resulted in it to have the highest stand count (Table 1). The variation among varieties could be as a result of genetic difference for root initiation and development [23]. The varieties which establish in short period of time are advantageous under limited moisture availability since they survive before the moisture is reduced. Department of Agriculture, Forestry and Fisheries [9] showed that stem cutting is a better method when the cuttings rapidly and easily take root and produce plants in general. Having earlier 50\% establishment does not always ensure the final stand count. Although "Qulle" showed the earliest establishment, its final stand count was the lowest. This could be due to the lowest tolerance of "Qulle" to biotic stress. On the contrary, "Hawassa-4" had the late establishment, but its final stand count was the highest. The reason could be that the variety had late root initiation and development but withstands the biotic stress. The final stand count is very important in selecting variety in 
TABLE 2: Mean values of number of primary stems per stake, number of branches per plant, plant height (cm), and multiplication ratio of four cassava varieties cultivated at Fafen district, ESRS.

\begin{tabular}{lcccc}
\hline Varieties & $\begin{array}{c}\text { Mean number of primary } \\
\text { stems/stake }\end{array}$ & $\begin{array}{c}\text { Mean number of secondary } \\
\text { branches/plant }\end{array}$ & $\begin{array}{c}\text { Mean plant height } \\
(\mathrm{cm})\end{array}$ & $\begin{array}{c}\text { Mean multiplication } \\
\text { ratio/stake }\end{array}$ \\
\hline Kello & $1.61^{\mathrm{b}}$ & $3.28^{\mathrm{c}}$ & $103.89^{\mathrm{c}}$ & $8.94^{\mathrm{c}}$ \\
Hawassa-4 & $2.17^{\mathrm{a}}$ & $4.72^{\mathrm{b}}$ & $91^{\mathrm{c}}$ & $14.22^{\mathrm{b}}$ \\
Qulle & $1.94^{\mathrm{ab}}$ & $7.61^{\mathrm{a}}$ & $148.56^{\mathrm{a}}$ & $24.94^{\mathrm{a}}$ \\
Chichu & $2.39^{\mathrm{a}}$ & $2.56^{\mathrm{d}}$ & $121.89^{\mathrm{b}}$ & 116.88 \\
Mean & 2.02 & 4.54 & 7.64 & $14.67^{\mathrm{b}}$ \\
CV(\%) & 16.3 & 15.23 & 5.93 & 15.69 \\
LSD & 0.60 & 0.46 & & 1.32 \\
\hline
\end{tabular}

TABLE 3: Average values for number of tubers/plant, length of tubers/plant, diameter of tubers/plant, tuber yield per plot, total tuber yield per hectare, and percent of dry matter content of four cassava varieties cultivated at Fafen district, ESRS.

\begin{tabular}{lccccccc}
\hline Varieties & $\begin{array}{c}\text { Number of } \\
\text { tubers/plant }\end{array}$ & $\begin{array}{c}\text { Length of } \\
\text { tubers/plant } \\
(\mathrm{cm})\end{array}$ & $\begin{array}{c}\text { Diameter of } \\
\text { tubers/plant }(\mathrm{cm})\end{array}$ & $\begin{array}{c}\text { Fresh tuber } \\
\text { weight/plant } \\
(\mathrm{kg})\end{array}$ & $\begin{array}{c}\text { Tuber yield } \\
\text { per plot }(\mathrm{kg})\end{array}$ & $\begin{array}{c}\text { Total tuber } \\
\text { yield }(\mathrm{t} / \mathrm{ha})\end{array}$ & $\begin{array}{c}\text { Dry matter } \\
\text { content of tubers } \\
(\%)\end{array}$ \\
\hline Kello & $5.44^{\mathrm{b}}$ & $25.39^{\mathrm{a}}$ & $3.24^{\mathrm{b}}$ & $1.99^{\mathrm{b}}$ & $11.94^{\mathrm{b}}$ & $19.90^{\mathrm{b}}$ & $44.62^{\mathrm{ab}}$ \\
Hawassa-4 & $6.50^{\mathrm{a}}$ & $22.11^{\mathrm{b}}$ & $3.87^{\mathrm{a}}$ & $2.39^{\mathrm{a}}$ & $14.36^{\mathrm{a}}$ & $23.93^{\mathrm{a}}$ & $50.28^{\mathrm{a}}$ \\
Qulle & $5.06^{\mathrm{b}}$ & $24.67^{\mathrm{ab}}$ & $2.84^{\mathrm{c}}$ & $1.87^{\mathrm{b}}$ & $11.24^{\mathrm{b}}$ & $18.73^{\mathrm{b}}$ & $43.94^{\mathrm{b}}$ \\
Chichu & $4.06^{\mathrm{c}}$ & $17.89^{\mathrm{c}}$ & $2.32^{\mathrm{d}}$ & $1.35^{\mathrm{c}}$ & $8.09^{\mathrm{c}}$ & $13.48^{\mathrm{c}}$ & $41.21^{\mathrm{b}}$ \\
Mean & 5.27 & 22.52 & 3.07 & 1.90 & 11.41 & 19.01 & 45.01 \\
CV (\%) & 12.87 & 8.42 & 8.33 & 12.81 & 12.81 & 12.81 & 20.04 \\
LSD & 0.45 & 1.26 & 0.17 & 0.97 & 5.83 & 0.97 \\
\hline
\end{tabular}

TABLE 4: Correlation matrix between yield and its components.

\begin{tabular}{|c|c|c|c|c|c|c|c|c|c|c|}
\hline Traits & SB & PS & $\mathrm{PH}$ & MR & $\mathrm{TN}$ & $\mathrm{TL}$ & TD & FW & TY & $\mathrm{DM}$ \\
\hline SB & 1 & & & & & & & & & \\
\hline PS & 0.029 & 1 & & & & & & & & \\
\hline $\mathrm{PH}$ & $0.513^{* *}$ & 0.007 & 1 & & & & & & & \\
\hline MR & $0.777^{* *}$ & 0.026 & $0.748^{* *}$ & 1 & & & & & & \\
\hline $\mathrm{TN}$ & 0.201 & -0.116 & $-0.459^{* *}$ & -0.126 & 1 & & & & & \\
\hline TL & $0.419^{* *}$ & $-0.290^{*}$ & 0.050 & 0.055 & $0.378^{* *}$ & 1 & & & & \\
\hline TD & 0.155 & -0.100 & $-0.533^{* *}$ & $-0.258^{*}$ & $0.729^{* *}$ & $0.339^{* *}$ & 1 & & & \\
\hline FW & $0.253^{*}$ & -0.157 & $-0.380^{* *}$ & -0.117 & $0.606^{* *}$ & $0.465^{* *}$ & $0.745^{* *}$ & 1 & & \\
\hline TY & $0.253^{*}$ & -0.157 & $-0.380^{* *}$ & -0.117 & $0.606^{* *}$ & $0.465^{* *}$ & $0.745^{* *}$ & $00.97^{* *}$ & 1 & \\
\hline $\mathrm{DM}$ & 0.051 & -0.117 & $-0.249^{*}$ & -0.042 & $0.359^{* *}$ & 0.099 & $0.266^{*}$ & -0.024 & -0.024 & 1 \\
\hline
\end{tabular}

$\mathrm{SB}=$ secondary branches, $\mathrm{PS}=$ primary stems, $\mathrm{PH}=$ plant height, $\mathrm{MR}=$ Multiplication ratio, $\mathrm{TN}=$ tuber number, $\mathrm{TL}=$ tuber length, $\mathrm{FW}=$ fresh weight, $\mathrm{TD}=$ tuber diameter, $\mathrm{TY}=$ total tuber yield, $\mathrm{DM}=$ dry matter content, ${ }^{*}$ significant, and ${ }^{* *}$ highly significant $(p \geq 0.35)$.

dry land areas for its drought tolerance. In general, cassava widely adapted to a variety of environmental conditions, but usually the adaptability of most varieties is narrow and shows large genotype $\mathrm{x}$ environment $(\mathrm{GxE})$ interaction effects [24].

4.2. Growth Performance of Cassava Varieties. When the number of leaf buds is higher with limited stake length, higher number of primary stems may sprout on. "Chichu" sprouted the highest number of primary stems per stake, whereas "Kello" produced the lowest (Table 2). The difference might arise due to the difference with the number of leaf buds where the shoots grow up which resulted from genetic variation among varieties. The primary stem of cassava plant usually produces two or three secondary branches [25]. Besides, the growing degree, branching rate, and leaves formation are varied because the environment affected the phenology and growth of cassava [26]. Each secondary branch produces tertiary branches. The varieties with higher branches are used to suppress the weeds than the varieties with less branches. Structural morphology of cassava genotypes influences yield and responses to weed management [27]. Variety "Qulle" had the highest number of secondary branches per plant (7.61) with rebranching up to third level and the lowest was counted in "Chichu." The lowest branching in "Chichu" produced the lowest leaves that indirectly limited the variety to have the lowest dry matter content. This may result in variety "Chichu" to have the lowest yield.

Cassava varieties plant height ranged from 95.8 to $101.5 \mathrm{~cm}$ at various nutrient compositions [28]. But this study showed that it ranged from $98.61 \mathrm{~cm}$ to $148.56 \mathrm{~cm}$. Variety "Qulle" showed the highest plant height $(148.56 \mathrm{~cm})$ and Hawassa-4 showed the lowest $(98.61 \mathrm{~cm}$ ) (Table 2). The genetic variation could contribute to plant height variation. 
The highest multiplication ratio of those cassava varieties is important for the production of stem cuttings for the next cropping seasons. The highest plant height of "Qulle" may contribute to the variety to have the highest multiplication ratio or planting materials (24.94). Multiplication ratio is important to get multiple stem cuttings to overcome seed problems [29].

\subsection{Tuber Yield and Yield Components of Cassava Varieties.} The tuber yield and its components varied across varieties $[30,31]$. The highest tuber yield $(23.93 \mathrm{t} / \mathrm{ha})$ was produced in variety "Hawassa-4" followed by "Kello" (19.9t/ha) and "Qulle" (18.73 t/ha) (Table 3). These yields were higher than the yield obtained in Eastern Africa countries such as Kenya, Uganda, and Tanzania in 2013 which was 15.89, 12.02, and $7.50 \mathrm{t} / \mathrm{ha}$, respectively [32]. But the yield obtained in this study was slightly lower than the yield obtained from the study of Tadesse et al. [33] who evaluated the performance of cassava varieties for tuber yield at potential moist areas (Jimma and Hawassa) and stressed areas (Amaro and Sekota) in Ethiopia. This might be due to the difference in genotype and environmental variation. Dry matter content, in this study, ranged from 41.21 to 50.28 in average of $45 \%$. It implies variety "Hawassa-4" showed the highest dry matter content and, hence, the higher yield. Other findings ranged from $10.7 \%$ to $57.2 \%$, with an average of $34.7 \%$ [34], and $29.8 \%$ to $40.7 \%$, with an average of $34.5 \%[35,36]$.

4.4. Relationship of Yield and Yield Components. Several authors [37-39] reported that storage root number, length, and diameter were the main yield components contributing to yield enhancement in cassava. Accordingly, in this study, higher values in tuber number, length, and diameter gave higher tuber yield per hectare in variety "Hawassa-4," suggesting that increment of those yield components tends to increase yield per hectare. According to the result of Amarullah et al. [40], the growth and yield parameter of cassava have some profound effect on the final tuber yield. In other ways, tuber yield was negatively correlated plant height, signifying that the tuber yield decreases when plant height gets higher (Table 4). This might be the partition of assimilate to vegetative growth rather than tuber.

\section{Conclusion}

Cassava is very important for the economy of several countries because of its broad adaptation to a variety of soil, climate, drought tolerance, ability to grow on marginal soil, and its starchy tuberous roots used as food source. However, for some extent, it seems to be neglected due to its long time for maturity and its hydrogen cyanide content. Therefore, it is better to develop higher yield, early mature cassava variety with reduced or without hydrogen cyanide content. In this study, variety "Hawassa-4" showed the best performance with regard to survivable rate and tuber yield per hectare. Therefore, variety "Hawassa-4" is recommended in test area. However, its yield performance across various agroecologies must be tested.

\section{Data Availability}

All of the data are available on the hand of the authors as is described in the results section.

\section{Conflicts of Interest}

The authors declare no conflicts of interest.

\section{Authors' Contributions}

This work was carried out in collaboration between both authors. The first author designed the experiment and analyzed the data. Both of the authors interpreted the data, read the final manuscript, and agreed with all contents.

\section{Acknowledgments}

The authors gratefully acknowledge Jigjiga University for providing financial support and farmers in Fafen district in Ethiopian Somali Regional State for keeping their experimental site.

\section{References}

[1] A. A. C. Alves, "Cassava botany and physiology," in Cassava: Biology, Production and Utilization, R. J. Hillocks, J. M. Thresh, and A. C. Bellotti, Eds., pp. 67-89, Cabi Publishing, Wallingford, UK, 2002.

[2] B. V. Le, B. L. Anh, K. Soytong, N. D. Danh, and L. T. Anh Hong, "Plant regeneration of cassava (Manihot esculenta CRANTZ) plants," Journal of Tropical Agriculture, vol. 3, pp. 121-127, 2007.

[3] Food and Agricultural Organization (FAO), FAOSTAT. Food and Agriculture Organization of the United Nations, FAO, Rome, Italy, 2014.

[4] F. I. Nweke, D. S. C. Spencer, and J. K. Lynam, The Cassava Transformation: Africa's Best-Kept Secret, pp. 1-7, Michigan State University Press, East Lansing, MI, USA, 2002.

[5] H. Ceballos, E. Okogbenin, and J. C. Pérez, "Cassava," in Root and Tuber Crops, Handbook of Plant Breeding, J. E. Bradshaw, Ed., vol. 7, pp. 53-96, Springer, New York, NY, USA, 2010.

[6] Food and Agricultural Organization (FAO), Food Outlook Global Market. Global Information and Early Warning System (GIEWS), p. 129, FAO, Rome, Italy, 2012.

[7] N. Amsalu, Characterization and Divergence Analysis in Cassava (Manihot esculenta Cranz) Genotypes at Jimma, M.S. thesis, Alemaya University, Dire Dawa, Ethiopia, 2003.

[8] M. Dejene, "The potentials and prospects of cassava as food security crop in Ethiopia," in Cassava Improvement to Enhance Livelihoods in Sub-Saharan Africa and Northeastern Brazil: First International Meeting on Cassava Breeding, Biotechnology and Ecology, R. Ortiz and N. M. A. Nassar, Eds., pp. 102-103, Universidade de Brasilia, Brasilia Brazil, 2006.

[9] Department of Agriculture, Forestry and Fisheries, Cassava Production Guide Lines Pretoria, South Africa, Department of Agriculture, Forestry and Fisheries, 2010.

[10] J. H. Cock, "Cassava: new potential for a neglected crop," in IADS Development-Orientated Literature Series, Westview Press, Boulder, CO, USA, 1985.

[11] H.-Q. Li, J.-Y. Guo, Y.-W. Huang et al., "Regeneration of cassava plants via shoot organogenesis," Plant Cell Reports, vol. 17, no. 5, pp. 410-414, 1998. 
[12] G. A. Schott, R. M. Best, and R. Bokanga, Roots and Tubers in the Global Food System: A Vision Statement to the Year 2020 Lima Peru, IITA, 2000.

[13] H. H. Sahel, Z. O. Thabit, and A. H. Ali, "On-farm evaluation of sweet potato varieties in Zanzibar," African Crop Science Journal, vol. 12, pp. 253-258, 2004.

[14] R. Kappinga, A. Westby, and A. Nsansugwanko, "Diversification of cassava in the lake zones of Tanzania," Journal of Tropical Agriculture, vol. 75, pp. 125-128, 1998.

[15] A. Nebiyu and E. Firidisa, "Effects of different proportions of Maize and soybean flours on cassava bread quality characteristics," in Proceedings of the First Conference on Ethiopian Horticultural Science Society(EHSS), vol. 1, Ethiopian Horticultural Science Society, Addis Ababa, Ethiopia, pp. 153-156, March 2006.

[16] L. Kuiper, B. Ekmecki, C. Hamelink, W. Hettinga, S. Meyer, and K. Koop, Bio-ethanol from Cassava, Ecofys Netherlands BV, Utrecht, The Netherlands, 2007.

[17] M. D. Andersen, P. K. Busk, I. Svendsen, and B. L. Møller, "Cytochromes P-450 from cassava (Manihot esculenta Crantz) catalyzing the first steps in the biosynthesis of the cyanogenic glucosides linamarin and lotaustralin," Journal of Biological Chemistry, vol. 275, no. 3, pp. 1966-1975, 2000.

[18] D. Leihner, "Agronomy and cropping systems," in Cassava: Biology, Production, and Utilization, R. J. Hillocks, Ed., pp. 91-113, CAB International, Oxfordshire UK, 2002.

[19] N. Malumo, Effect of Cassava Stake Orientation and Planting Depth on Planting Material Multiplication atio Tuberous Root Yield, M.S. thesis, University of Zambia, Lusaka, Zambia, 2001.

[20] J. A. Otoo, Rapid Multiplication of Cassava. Research Guide, IITA, Ibadan, Nigeria, 1996.

[21] C. J. M. Almekinders and N. P. Louwaars, Farmers' Seed Production: New Approaches and Practices, pp. 215-227, Intermediate Technology Publications, London, UK, 1999.

[22] K. A. Gomez and A. A. Gomez, Statistical Procedures for Agricultural Research (2ed), p. 680, A Wiley-Inter science Publication, Hoboken, NJ, USA, 1984.

[23] S. P. Ghosh, T. Ramanjuman, J. S. Jos, S. N. Moorthey, and R. G. Nair, Tuber Crops, pp. 108-117, Oxford and IBH publishing company, New Delhi, India, 1988.

[24] K. Noerwijati and R. Budiono, "Yield and yield components evaluation of cassava (manihot esculenta Crantz) clones in different altitudes," Energy Procedia, vol. 65, pp. 155-161, 2015.

[25] I. J. Ekanayake, D. S. O. Osiru, and M. C. M. Porto, Agronomy of Cassava IITA Research Guide 60, IITA, Ibadan, Nigeria, 1997.

[26] V. Sarawat, S. Ratanasriwong, K. Puangprakon, and A. Jintrawet, "The development of a cassava growth model in Thailand," in Proceedings of the Sixth Regional Workshop, CABI Publishing, Ho Chi Minh City, Vietnam, February 2000.

[27] A. E. Agahiu, K. P. Baiyeri, and R. O. Ogbuji, "Structural morphology of cassava (Manihot esculenta Crantz) genotypes influenced yield and responses to weed management in the Guinea savanna zone of Nigeria," Journal of Applied Biosciences, vol. 48, pp. 3270-3278, 2011.

[28] RTIP (Root and Tuber Improvement Program), Annual Report, RTIP, Mansa, Zambia, 1998.

[29] E. K. Chikwado, Cassava Stem Multiplication Technology: A Viable Option for Industry Development?, National Root Crops Research Institute (NRCRI), Umudike, Nigeria, 2012.
[30] F. Apea-Bah, I. Oduro, W. O. Ellis, and O. Safo-Kantanka, "Factor analysis and age at harvest effect on the quality of flour from four cassava varieties," World Journal of Dairy and Food Sciences, vol. 6, no. 1, pp. 43-54, 2011.

[31] T. Mulualem and B. Ayenew, "Cassava (Mannihot esculenta cranz) varieties and harvesting stages influenced yield and yield related components," Journal of Natural Sciences Research, vol. 2, no. 10, pp. 122-128, 2012.

[32] Food and Agricultural Organization (FAO) STAT, Statistical Data Base of the Food and Agricultural Organization of the United Nations, Food and Agriculture Organization Corporate Statistical Database, Rome, Italy, 2013.

[33] T. Tadesse, A. Bekele, E. Tsegaye et al., "Performance of cassava (Manihot esculanta. Cratz) clones in potential and low moisture stressed areas of Ethiopia," Greener Journal of Agricultural Sciences, vol. 3, no. 4, pp. 262-270, 2017.

[34] A. L. Chávez, T. Sánchez, G. Jaramillo et al., "Variation of quality traits in cassava roots evaluated in landraces and improved clones," Euphytica, vol. 143, no. 1-2, pp. 125-133, 2005.

[35] G. Ramanandam, C. Ravisankar, and D. Srihari, "Integrated nutrient management for cassava under rain fed conditions of Andhra Pradesh," Journal of Root Crops, vol. 34, no. 2, pp. 129-136, 2008.

[36] E. Teye, A. P. Asare, R. S. Amoah, and J. P. Tetteh, "Determination of the dry matter content of cassava (Manihot esculenta, Crantz) tubers," ARPN Journal of Agricultural and Biological Science, vol. 6, no. 11, pp. 23-28, 2011.

[37] A. E. Agahiu, K. P. Baiyeri, and R. O. Ogbuji, "Correlation analysis of tuber yield and yield related characters in two cassava (Manihot esculenta Crantz) morphological-types grown under nine weed management systems in the Guinea savanna zone of Nigeria," Journal of Applied Biosciences, vol. 48, pp. 3316-3321, 2011.

[38] M. S. A. Fakir, M. H. R. Talukder, M. G. Mostafa, and M. S. Rahman, "De-branching effect on growth and yield in cassava," Journal of Agroforestry and Environment, vol. 5, no. 1, pp. 1-5, 2011.

[39] P. Ntawuruhunga and A. Dixon, "Quantitative variation and interrelationship between factors influencing cassava yield," Journal of Applied Biosciences, vol. 26, pp. 594-1602, 2010.

[40] A. Amarullah, D. Indradewa, P. Yudono, and B. Sunarminto, "Correlation of growth parameters with yield of two cassava varieties," Ilmu Pertanian (Agricultural Science), vol. 1, no. 3, p. 100, 2017. 